\title{
Assessment of students' satisfaction with nursing studies at the Faculty of Health Science, Warsaw Medical University. Pilot study
}

\section{Ocena zadowolenia studentów z ksztatcenia na kierunku pielęgniarstwo na Wydziale Nauki o Zdrowiu Warszawskiego Uniwersytetu Medycznego. Doniesienie wstępne}

\author{
Joanna Gotlib, Iwona Redel², Grzegorz Stachacz², Anna Kaczyńska², Jarosława Belowskaํ, Mariusz Panczyk ${ }^{1}$ \\ 'Division of Teaching and Outcomes of Education, Faculty of Heath Science, Medical University of Warsaw, Poland \\ Head of Division: Prof. Joanna Gotlib MD, PhD \\ 2Faculty of Health Science, Medical University of Warsaw, Poland \\ Head of Faculty: Prof. Piotr Małkowski MD, PhD
}

Key words: efficacy, effectiveness, quality of teaching, satisfaction of students

Słowa kluczowe: skuteczność, efektywność, jakość kształcenia, satysfakcja studentów.

\begin{abstract}
Introduction: The analysis of the opinions of students regarding their level of satisfaction with their studies constitutes one of the basic elements of global assessment of the quality of teaching at university-level schools.

Aim of the research: To analyse the assessment of satisfaction of students with the learning content and teaching methods in the field of nursing at the Faculty of Health Science, Medical University of Warsaw.

Material and methods: The study enrolled 200 full-time (ST) and part-time (NST) students, including 195 women (F) and 5 men (M). The mean age was 34 years and the questionnaire return rate was $55 \%$. This was a voluntary and anonymous questionnaire study, with a questionnaire developed by the authors including 27 close-ended questions. The students received the questionnaire in the form of a link to an e-form. Statistical analysis was performed using Statsoft Statistica 10.0 (licensed to Medical University of Warsaw) and Mann-Whitney $U$ test (significance level: $p<0.05$ ).

Results: The majority of ST and NST students were satisfied with studying Nursing at Medical University of Warsaw. The vast majority of the study participants reported that the number of hours of lectures was sufficient, with ST students reporting thois significantly more often $(p<0.05)$. The students from both groups reported that the number of hours of seminars, classes and professional training sessions was sufficient $(p=\mathrm{NS})$. The vast majority of the ST and NST students expressed a preference to choose theoretical classes and seminars on their own, in accordance with their interests and the character of their job. Compared to the ST students, the NST students significantly more often $(p<0.05)$ declared that the curriculum did not include a sufficient number of hours of the following courses: Contracting Health Benefits, Law in Health Protection and European Nursing. Conclusions: Teaching in the field in Nursing met with the expectations of both ST and NST students from the study group. The mode of study may influence the expectations of students regarding the curriculum, learning content and organisation of the course, as well as the level of satisfaction with education received. In the study group, the part-time students had greater expectations regarding the structure of the curriculum and the learning content. The students' level of satisfaction with learning should be assessed on a regular basis for continuous improvement and maintenance of high quality of teaching, and the study results should be introduced into the curriculum, learning content and teaching methods.
\end{abstract}

\section{Streszczenie}

Wprowadzenie: Analiza opinii studentów na temat zadowolenia ze studiowania jest jednym z podstawowych elementów oceny globalnej jakości kształcenia na uczelniach.

Cel pracy: Analiza oceny zadowolenia studentów z treści i metod kształcenia na kierunku pielęgniarstwo na Wydziale Nauki o Zdrowiu Warszawskiego Uniwersytetu Medycznego.

Materiał i metody: W badaniu wzięło udział 200 studentów studiów stacjonarnych (ST) i niestacjonarnych (NST), w tym 195 kobiet i 5 mężczyzn. Średnia ich wieku wynosiła 34 lata, a odsetek zwrotu ankiet 55\%. W badaniu wykorzystano dobrowolne, anonimowe badania ankietowe - samodzielnie skonstruowany kwestionariusz zawierający 27 pytań zamkniętych. Studenci otrzymywali kwestionariusz w formie linku do elektronicznego formularza. Przeprowadzono analizę statystyczną: StatSoft Statistica 10.0, test $U$ Manna-Whitneya $(p<0,05)$.

Wyniki: Większość studentów ST i NST była zadowolona z kształcenia na kierunku pielęgniarstwo na Warszawskim Uniwersytecie Medycznym. Większość również deklarowała, że liczba godzin wykładów była wystarczająca (ST istotnie częściej 
$-p<0,05)$. W obu grupach studenci stwierdzali, że liczba godzin zajęć seminaryjnych, ćwiczeń oraz praktyk zawodowych była wystarczająca ( $p=$ NS). Zdecydowana większość studentów ST i NST chciałaby decydować o wyborze zajęć teoretycznych i seminaryjnych zgodnie z zainteresowaniami i specyfiką pracy. Studenci NST istotnie częściej niż ST ( $p<0,05)$ podawali, że w programie studiów jest za mało godzin kształcenia z takich przedmiotów, jak: kontraktowanie świadczeń medycznych, prawo w ochronie zdrowia, pielęgniarstwo europejskie.

Wnioski: W grupie badanej kształcenie na kierunku pielęgniarstwo spełniło oczekiwania zarówno studentów ST, jak i NST. Tryb studiów może wpływać na oczekiwania studentów wobec programu studiów, treści i organizacji kształcenia oraz poziom ich satysfakcji z otrzymanego wykształcenia. Studenci NST mieli większe oczekiwania wobec konstrukcji programu kształcenia oraz treści kształcenia przekazywanych podczas studiów. W celu ciągłego podnoszenia i utrzymywania wysokiej jakości kształcenia badania dotyczące zadowolenia studentów ze studiowania powinny być prowadzone regularnie, a ich wyniki implementowane do programów studiów, treści i stosowanych metod kształcenia.

\section{Introduction}

In accordance with the European Agreement on the Instruction and Education of Nurses and Midwives, drawn up in Strasbourg on 25 October, 1967 (Journal of Laws/Dz.U.96.83.384) and the Requirements on Teaching Nurses and Midwives resulting from Directive 2005/36/EC of the European Parliament and of the Council of 7 September, 2005, on the recognition of professional qualifications (O.J. EU L.05.255.22), nurses should receive university-level education [1].

The assurance of proper completion of a curriculum and the development of an internal teaching quality assessment system that includes education quality assessment tools and assessment methods, constitute essential elements for the evaluation of a university-level school offering nursing programmes for students [2-4]. Analysis of the level of students' satisfaction with learning is one of the most important elements of an internal teaching quality assessment system of every school [2-6].

\section{Aim of the research}

The aim of the study was to assess the satisfaction of students with the learning content and teaching methods in the field of nursing at the Faculty of Health Science, Warsaw Medical University. A detailed aim of the study was to compare the level of satisfaction with learning among nursing students between full-time MA students (ST) and part-time MA students (NST) at the Faculty of Health Science, Medical University of Warsaw.

\section{Material and methods}

All second-year full-time and part-time students of a Master's degree course in Nursing at the Faculty of Health Science, Medical University of Warsaw, were invited to the study. The invitation to participate in the study was sent to personal email addresses of students registered in the University Central Students Database that is used by, among others, the Dean's Office staff of the University. The total number of students invited to take part in the study amounted to 362 persons (164 full-time and 198 part-time students).

Finally, the study involved a total of 200 students: 195 women and 5 men, aged between 20 and 56 years (mean age: 34 years). The questionnaire return rate was $55 \%$. Among the study group, $96 \%$ of the ST students and $99 \%$ of the NST students worked as a nurse during the time of the study.

The study was performed in March and April, 2012. Participation in the survey was voluntary. An anonymous questionnaire developed by the authors comprising a total of 27 close-ended questions constituted the research tool. The students received the questionnaire in the form of a link to an e-form. Answers to the questions were automatically saved in a Microsoft Excel document.

\section{Statistical analysis}

StatSoft Statistica 10.0 software (licensed to Warsaw Medical University) was used for statistical analysis of the results [5]. Owing to the fact that two separate groups of students: full-time (ST) students (group 1) and part-time (NST) students(group 2), were compared and due to the nature of the data (qualitative, non-parametric data) and the absence of normal distribution of the data (Shapiro-Wilk test: $p>0.05$ ), the non-parametric Mann-Whitney $U$ test was used for the statistical analysis. The significance level was established at $p<0.05$.

\section{Results}

The majority of ST and NST students were satisfied with studying Nursing at Medical University of Warsaw. The vast majority of the students reported that the number of lectures was sufficient. However, the difference between ST and NST students was statistically significant $(p<0.05)$; ST students more often said that the number of lectures was appropriate. The students from both groups reported that the number of hours of seminars, classes and professional training sessions was sufficient ( $p=\mathrm{NS}$ ). The vast majority of the ST and NST students expressed a preference to choose theoretical classes and seminars on their own, in accordance with their interests and the character of their job. See Table 1 for detailed data.

Among the study group, NST students, compared to ST students, significantly more often $(p<0.05)$ said that the curriculum of the MA programme in nursing included too few teaching hours in the following cours- 
Table 1. Opinions of students on MA programme in Nursing at the Faculty of Health Science, Medical University of Warsaw

\begin{tabular}{|c|c|c|c|c|c|}
\hline No. & Question & & $\begin{array}{l}\text { Opinions of full- } \\
\text { time students } \\
\begin{array}{c}\text { (ST }-n=164) \\
n /(\%)\end{array}\end{array}$ & $\begin{array}{l}\text { Opinions of part- } \\
\text { time students } \\
\text { (ST }-n=198) \\
n /(\%)\end{array}$ & $\begin{array}{l}\text { Significance } \\
\text { level } p\end{array}$ \\
\hline 1 & $\begin{array}{l}\text { Number of hours } \\
\text { of lectures }\end{array}$ & $\begin{array}{l}\text { Too small } \\
\text { Too high } \\
\text { Sufficient }\end{array}$ & $\begin{array}{c}6 / 3 \\
22 / 14 \\
136 / 83\end{array}$ & $\begin{array}{c}25 / 13 \\
17 / 9 \\
154 / 78\end{array}$ & 0.05 \\
\hline 2 & $\begin{array}{l}\text { Number of hours } \\
\text { of seminars }\end{array}$ & $\begin{array}{l}\text { Too small } \\
\text { Too high } \\
\text { Sufficient }\end{array}$ & $\begin{array}{c}2 / 1 \\
42 / 26 \\
119 / 73\end{array}$ & $\begin{array}{c}4 / 2 \\
40 / 20 \\
154 / 78\end{array}$ & NS \\
\hline 3 & $\begin{array}{l}\text { Number of hours } \\
\text { of classes and } \\
\text { professional } \\
\text { trainings }\end{array}$ & $\begin{array}{l}\text { Too small } \\
\text { Too high } \\
\text { Sufficient }\end{array}$ & $\begin{array}{c}18 / 11 \\
16 / 10 \\
129 / 79\end{array}$ & $\begin{array}{c}18 / 9 \\
61 / 31 \\
118 / 60\end{array}$ & NS \\
\hline 4 & \multicolumn{2}{|c|}{$\begin{array}{l}\text { Willingness to decide on theoretical classes } \\
\text { compliant with interests and character of their job }\end{array}$} & $162 / 99$ & $180 / 91$ & NS \\
\hline 5 & \multicolumn{2}{|c|}{$\begin{array}{l}\text { Willingness to decide on seminars compliant with } \\
\text { interests and character of their job }\end{array}$} & $162 / 99$ & $180 / 91$ & NS \\
\hline 6 & $\begin{array}{l}\text { Usefulness } \\
\text { of particular } \\
\text { teaching methods } \\
\text { in training of } \\
\text { nurses }\end{array}$ & $\begin{array}{l}\text { Lecture } \\
\text { Mini-lecture } \\
\text { Multimedia presentation } \\
\text { Simulation games } \\
\text { e-Learning } \\
\text { Instruction } \\
\text { Demonstration } \\
\text { Classes }\end{array}$ & $\begin{array}{c}18 / 11 \\
16 / 10 \\
91 / 56 \\
19 / 12 \\
132 / 81 \\
114 / 70 \\
116 / 71 \\
123 / 75\end{array}$ & $\begin{array}{c}16 / 8 \\
24 / 12 \\
134 / 68 \\
16 / 8 \\
168 / 85 \\
178 / 90 \\
166 / 84 \\
160 / 81\end{array}$ & NS \\
\hline 7 & $\begin{array}{l}\text { Assessment of } \\
\text { availability of } \\
\text { lecturers during } \\
\text { consultation } \\
\text { hours }\end{array}$ & $\begin{array}{l}\text { Easily available } \\
\text { Limited availability } \\
\text { Rather available } \\
\text { Unavailable }\end{array}$ & $\begin{array}{l}82 / 50 \\
83 / 31 \\
32 / 20 \\
16 / 10\end{array}$ & $\begin{array}{l}24 / 12 \\
69 / 35 \\
110 / 56 \\
140 / 71\end{array}$ & 0.001 \\
\hline 8 & $\begin{array}{l}\text { Satisfaction of } \\
\text { students with } \\
\text { choosing their } \\
\text { major }\end{array}$ & $\begin{array}{l}\text { Strongly yes } \\
\text { Rather yes } \\
\text { Rather no } \\
\text { Strongly no }\end{array}$ & $\begin{array}{l}65 / 40 \\
93 / 57 \\
3 / 2 \\
2 / 1\end{array}$ & $\begin{array}{c}118 / 60 \\
104 / 33 \\
4 / 2 \\
6 / 3\end{array}$ & NS \\
\hline
\end{tabular}

$p$ - significance level, NS (not significant) - difference statistically insignificant. The answers do not sum up to $100 \%$ because more than one answer was possible for this question

es: Contracting Health Benefits, Law in Health Protection and European Nursing. See Table 2 for detailed data.

Compared to ST students, NST students significantly more often $(p<0.05)$ recognized the usefulness of the knowledge of the following courses: clinical sciences, managing in nursing, contracting health benefits, law in health protection, European nursing, teaching in nursing, nursing theories, and Psychotherapy. See Table 3 for detailed data.

\section{Discussion}

The available Polish scientific literature (Polish Medical Bibliography - PBL, records: students, nursing, satisfaction with learning) presents a multitude of publications directly or indirectly devoted to the assessment of teaching quality in the field of nursing at Polish university-level schools [7-24].

The level of teaching in the field of nursing at the Faculty of Health Science, Medical University of Warsaw, was assessed highly by the students in the present study. In our study, the level of satisfaction with learning was close to or higher than those obtained by other authors [7-13, 17-24].

Most study participants assessed highly the qualifications of lecturers and teaching content of particular courses. The study participants found the knowledge of cardiac nursing and law in health protection very useful in their professional activity. The knowl- 
Table 2. Opinions of students on teaching content of MA programme in Nursing at the Faculty of Health Science, Medical University of Warsaw

\begin{tabular}{|c|c|c|c|c|c|c|}
\hline \multirow[t]{2}{*}{ No. } & \multirow[t]{2}{*}{ Course } & \multicolumn{2}{|c|}{$\begin{array}{l}\text { Opinions of full-time } \\
\text { students } \\
\begin{array}{c}\text { (ST }-n=164) \\
n /(\%)\end{array}\end{array}$} & \multicolumn{2}{|c|}{$\begin{array}{c}\text { Opinions of part-time } \\
\text { students } \\
(\mathrm{ST}-n=198) \\
n /(\%)\end{array}$} & \multirow[t]{2}{*}{$\begin{array}{c}\text { Significance } \\
\text { level } p\end{array}$} \\
\hline & & $\begin{array}{l}\text { Too little } \\
\text { number } \\
\text { of teaching } \\
\text { hours }\end{array}$ & $\begin{array}{c}\text { Appropriate } \\
\text { number } \\
\text { of teaching } \\
\text { hours }\end{array}$ & $\begin{array}{l}\text { Too little } \\
\text { number } \\
\text { of teaching } \\
\text { hours }\end{array}$ & $\begin{array}{l}\text { Appropriate } \\
\text { number } \\
\text { of teaching } \\
\text { hours }\end{array}$ & \\
\hline \multicolumn{7}{|c|}{ General education courses } \\
\hline 1 & Nursing theories & $5 / 3$ & $111 / 68$ & $16 / 8$ & $155 / 78$ & NS \\
\hline 2 & Teaching in nursing & $3 / 2$ & $69 / 41$ & $16 / 8$ & $95 / 48$ & NS \\
\hline 3 & Managing in nursing & $16 / 10$ & $136 / 69$ & $34 / 17$ & $126 / 64$ & NS \\
\hline 4 & Contracting health benefits & $10 / 6$ & $99 / 50$ & $45 / 23$ & $112 / 57$ & 0.05 \\
\hline 5 & Law in health protection & $21 / 13$ & $135 / 68$ & $63 / 32$ & $126 / 64$ & 0.05 \\
\hline 6 & Psychotherapy & $8 / 5$ & $91 / 46$ & $22 / 11$ & $112 / 57$ & NS \\
\hline 7 & European nursing & $10 / 6$ & $149 / 75$ & $34 / 17$ & $132 / 67$ & 0.05 \\
\hline \multicolumn{7}{|c|}{ Public health } \\
\hline 8 & Health promotion & $13 / 8$ & $158 / 80$ & $26 / 13$ & $148 / 75$ & NS \\
\hline \multicolumn{7}{|c|}{ Clinical nursing } \\
\hline 9 & Clinical sciences & $16 / 10$ & $111 / 68$ & $28 / 14$ & $134 / 68$ & NS \\
\hline 10 & Nephrological nursing & $18 / 11$ & $116 / 71$ & $47 / 24$ & $124 / 63$ & NS \\
\hline 11 & Cardiac nursing & $42 / 26$ & $108 / 66$ & $47 / 24$ & $135 / 68$ & NS \\
\hline 12 & Long-term care nursing & $21 / 13$ & $106 / 65$ & $40 / 20$ & $124 / 63$ & NS \\
\hline 13 & Paediatric surgical nursing & $22 / 14$ & $111 / 68$ & $58 / 29$ & $122 / 62$ & NS \\
\hline 14 & Family nursing & $14 / 9$ & $118 / 72$ & $22 / 11$ & $126 / 64$ & NS \\
\hline
\end{tabular}

$p$-significance level, NS (not significant) - difference statistically insignificant

edge of the fields of psychotherapy and teaching in nursing was indicated as the least useful; therefore, it might be presumed that students defined the usefulness of the courses according to the possibility of using the acquired knowledge in practice. Most of the study participants were willing to choose theoretical courses, seminars and classes on their own in accordance with their interests and the character of their job.

According to the study group, the number of hours of seminars and theoretical classes offered in the curriculum was sufficient. The number of hours of seminars was too high for approximately one in five of the study participants. The number of hours of classes and professional trainings was sufficient for most study participants. According to the study population, the various teaching methods used to train nursing students were suitable for the teaching con- tent; among the most frequent methods used during practical classes were the following: demonstration of activities, instruction, participation-based teaching and consolidation activities. Most study participants believed that consolidation activities were the most useful in teaching nurses.

The present study demonstrated that students considered the facilities and infrastructure of Warsaw Medical University as satisfactory; equipment and facilities in lecture halls were rated highest, whereas the catering and functioning of the Dean's Office were rated lowest. Organisation of the course of studies was rated lowest by students from other university-level schools [13-19]. The functioning of the school administration and Dean's Office is one of many aspects of the organisation of the course of studies that needs improvement. Other university-level schools also share this problem [21-24]. 
Table 3. Usefulness of knowledge acquired during MA programme in Nursing according to the study group of students

\begin{tabular}{|c|c|c|c|c|c|c|c|c|c|c|}
\hline \multirow[t]{2}{*}{ No. } & \multirow[t]{2}{*}{ Course } & \multicolumn{4}{|c|}{$\begin{array}{l}\text { Opinions of full-time students } \\
\text { (ST }-n=164) \\
n /(\%)\end{array}$} & \multicolumn{4}{|c|}{$\begin{array}{l}\text { Opinions of part-time students } \\
\text { (NST }-n=198) \\
n /(\%)\end{array}$} & \multirow[t]{2}{*}{$\begin{array}{l}\text { Signifi- } \\
\text { cance } \\
\text { level } p\end{array}$} \\
\hline & & $\begin{array}{l}\text { Very } \\
\text { useful }\end{array}$ & $\begin{array}{l}\text { Rather } \\
\text { useful }\end{array}$ & $\begin{array}{l}\text { Rather } \\
\text { not } \\
\text { useful }\end{array}$ & $\begin{array}{l}\text { Not } \\
\text { useful }\end{array}$ & $\begin{array}{l}\text { Very } \\
\text { useful }\end{array}$ & $\begin{array}{l}\text { Rather } \\
\text { useful }\end{array}$ & $\begin{array}{l}\text { Rather } \\
\text { not } \\
\text { useful }\end{array}$ & $\begin{array}{l}\text { Not } \\
\text { useful }\end{array}$ & \\
\hline \multicolumn{11}{|c|}{ General education courses } \\
\hline 1 & Nursing theories & $11 / 7$ & $109 / 67$ & $32 / 20$ & $8 / 6$ & $49 / 25$ & $110 / 56$ & $23 / 12$ & $13 / 7$ & 0.05 \\
\hline 2 & $\begin{array}{l}\text { Teaching } \\
\text { in nursing }\end{array}$ & $3 / 2$ & $66 / 40$ & $82 / 50$ & $13 / 8$ & $49 / 25$ & $87 / 44$ & $51 / 26$ & $10 / 5$ & 0.05 \\
\hline 3 & $\begin{array}{l}\text { Managing } \\
\text { in nursing }\end{array}$ & $18 / 11$ & $118 / 72$ & $21 / 13$ & $6 / 4$ & $77 / 39$ & $91 / 46$ & $23 / 12$ & $6 / 3$ & 0.05 \\
\hline 4 & $\begin{array}{l}\text { Contracting } \\
\text { health benefits }\end{array}$ & $15 / 9$ & $66 / 40$ & $77 / 47$ & $6 / 4$ & $61 / 31$ & $77 / 39$ & $49 / 25$ & $10 / 5$ & 0.05 \\
\hline 5 & $\begin{array}{l}\text { Law in health } \\
\text { protection }\end{array}$ & $34 / 21$ & $118 / 72$ & $10 / 6$ & $2 / 1$ & $112 / 57$ & $81 / 41$ & $4 / 2$ & - & 0.05 \\
\hline 6 & Psychotherapy & $8 / 5$ & $61 / 37$ & $62 / 38$ & $32 / 20$ & $49 / 25$ & $67 / 34$ & $43 / 22$ & $36 / 19$ & 0.05 \\
\hline 7 & $\begin{array}{l}\text { European } \\
\text { nursing }\end{array}$ & $13 / 8$ & $114 / 70$ & $29 / 18$ & $6 / 4$ & $53 / 27$ & $102 / 52$ & $21 / 11$ & $19 / 10$ & 0.05 \\
\hline \multicolumn{11}{|c|}{ Public health } \\
\hline 8 & $\begin{array}{l}\text { Health } \\
\text { promotion }\end{array}$ & $18 / 11$ & $126 / 77$ & $18 / 11$ & $2 / 1$ & $65 / 33$ & $108 / 55$ & $18 / 9$ & $6 / 3$ & NS \\
\hline
\end{tabular}

Clinical nursing

\begin{tabular}{|c|c|c|c|c|c|c|c|c|c|c|}
\hline 9 & Clinical sciences & $42 / 26$ & $119 / 73$ & $2 / 1$ & - & $89 / 45$ & $106 / 54$ & $2 / 1$ & - & 0.05 \\
\hline 10 & $\begin{array}{l}\text { Nephrological } \\
\text { nursing }\end{array}$ & $28 / 17$ & $103 / 63$ & 29/18 & $3 / 2$ & $63 / 32$ & $106 / 54$ & $22 / 11$ & $5 / 3$ & NS \\
\hline 11 & Cardiac nursing & $54 / 33$ & $108 / 66$ & $2 / 1$ & - & $104 / 53$ & $87 / 44$ & $4 / 2$ & $2 / 1$ & NS \\
\hline 12 & $\begin{array}{l}\text { Long-term care } \\
\text { nursing }\end{array}$ & $34 / 21$ & $121 / 74$ & $5 / 3$ & $3 / 2$ & $83 / 42$ & $100 / 51$ & $8 / 4$ & $6 / 3$ & NS \\
\hline 13 & $\begin{array}{l}\text { Paediatric } \\
\text { surgical nursing }\end{array}$ & $29 / 18$ & $100 / 61$ & $31 / 19$ & $3 / 2$ & $57 / 29$ & $97 / 49$ & $32 / 16$ & $12 / 6$ & NS \\
\hline 14 & Family nursing & $32 / 20$ & $113 / 69$ & $13 / 8$ & $5 / 3$ & $57 / 29$ & $91 / 46$ & $36 / 18$ & $14 / 7$ & NS \\
\hline
\end{tabular}

$p$ - significance level, NS (not significant) - difference statistically insignificant

\section{Conclusions}

Teaching in the field in nursing met the expectations of both ST and NST students from the study group. The mode of study may influence the expectations of students regarding the curriculum, learning content and organisation of the course, as well as the level of satisfaction with education received. In the study group, the part-time students had greater expectations regarding the structure of the curriculum and the learning content. The level of satisfaction of students with learning should be assessed on a regular basis for continuous improvement and main- tenance of high quality of teaching, and the study results should be introduced into the curriculum, learning content and teaching methods.

\section{References}

1. Porozumienie $\mathrm{w}$ sprawie szkolenia i kształcenia pielęgniarek, sporządzonego w Strasburgu w 1967 r., podpisanego przez rząd RP w grudniu 1995 r. (Dz. U. Nr 83, poz. $384,385)$.

2. Standardy i wskazówki dotyczące zapewnienia jakości kształcenia w EOSW - dokument opracowany przez ENQA, przyjęty na Konferencji Ministrów w Bergen, 2005 r. 
3. Łącała Z, Noworol C. Ocena jakości kształcenia w kontekście zarządzania uczelnią wyższą. In: Ewolucja kształcenia w szkole wyższej. Brzezińska A, Brzeziński J (eds.). Fundacja Humaniora, Poznań 2000.

4. Wspólna Deklaracja Europejskich Ministrów Edukacji zebranych w Bolonii w dniu 19 czerwca 1999 r. In: Europejski Obszar Szkolnictwa Wyższego. Antologia dokumentów i materiałów, Kielce, 2006.

5. StatSoft Statistica 10.0. Available at: http://www.statsoft. $\mathrm{pl} / \mathrm{pdf} /$ nowosci10.html [12.11.2012 r.].

6. Binkowska-Bury M, Penar-Zadarko M, Marć M. Oczekiwania studentów kierunku pielęgniarstwo i położnictwo od nauczyciela zawodu względem procesu kształcenia. Problemy Pielęgniarstwa 2008; 1-2: 81-8.

7. Ławska W, Dębska G, Zięba M. Przygotowanie zawodowe i plany absolwentów kierunku pielęgniarstwo w Podhalańskiej Państwowej Wyższej Szkole Zawodowej w Nowym Targu. Problemy Pielęgniarstwa 2010; 18: 163-8.

8. Krajewska-Kułak E, Lewko J, Jankowska B. Ocena systemu kształcenia licencjackiego na kierunku pielęgniarstwo w opinii studentów Wydziału Pielęgniarstwa i Ochrony Zdrowia. Akademia Medyczna w Białymstoku. Pielęgniarstwo XXI wieku 2006; 1/2: 201-14.

9. Walas L, Adamska-Kuźmicka I, Czekirda M. Zajęcia praktyczne w opinii studentów na przykładzie studiów I stopnia kierunku pielęgniarstwo w Akademii Medycznej w Lublinie. Problemy Pielęgniarstwa 2006; 2: 168-71.

10. Górajek-Jóźwik J. Samoocena studentów na przykładzie nauczania procesu pielęgnowania w Wydziale Pielęgniarskim w Lublinie. Wybrane Zagadnienia Pielęgniarstwa 2002; XXI: 175-9.

11. Gawin E, Cylkowska-Nowak M. Czynniki warunkujące sukces w studiowaniu pielęgniarstwa w opinii studentów Wydziału Pielęgniarskiego Akademii Medycznej w Lublinie i Poznaniu. Postępy Pielęgniarstwa i Promocji Zdrowia 1996; IX: 30-6.

12. Marć M, Binkowska-Bury M, Penar-Zadarko B. Wymagania stawiane nauczycielom zawodu pielęgniarstwo przeszłość, teraźniejszość, przyszłość. Wydział Medyczny Uniwersytetu Rzeszowskiego. Problemy Pielęgniarstwa 2008; 16: 36-42.

13. Mianowana V, Kościołek A. Ocena działalności dydaktycznej nauczycieli akademickich jako jeden z determinantów jakości kształcenia. Pielęgniarstwo XXI wieku 2009; 1/2: 12-9.

14. Gotlib J, Pakuła J. Samoocena przygotowania zawodowego studentek położnictwa Warszawskiego Uniwersytetu Medycznego. Przegląd Medyczny Uniwersytetu Rzeszowskiego i Narodowego Instytutu Leków w Warszawie Rzeszów 2012; 1: 74-85.

15. Gotlib J, Durka M, Goworek P. Analiza samooceny kompetencji zawodowych studentek położnictwa Warszawskiego Uniwersytetu Medycznego. Polski Przegląd Nauk o Zdrowiu 2008; 23: 23-6.

16. Gotlib J, Rebandel H. Samoocena kompetencji zawodowych studentów kierunku pielęgniarstwo w Akademii Medycznej w Warszawie. Pielęgniarstwo XXI Wieku 2007; 3/4: 15-23.

17. Łącała Z, Noworol C. Ocena jakości kształcenia w kontekście zarządzania uczelnią wyższą. In: Ewaluacja procesu kształcenia w szkole wyższej. Brzezińska A, Brzeziński J (eds.). Wydawnictwo Fundacji Humaniora, Poznan 2000.
18. Kózka M, Wrońska I. Projekt TUNING (TUNING Educational Structures in Europe). In: Wybrane zagadnienia z pielęgniarstwa europejskiego. Wrońska I, Krajewska Kułak E (eds.). Wydawnictwo Czelej, Lublin 2007; 106-8.

19. Figlewicz R. Metoda badania zadowolenia ze studiowania. Doskonalenie jakości zarządzania uczelnią. Innowacje w Edukacji Akademickiej 2002. Available at: www.cbe.wshe.lodz.pl/ /archiwalna_cbrk/artykuły.html; 12.03.2008.

20. Sadurska A, Wrońska I, Walas L, et al. Satysfakcja studentów ze studiów na kierunku pielęgniarstwo Uniwersytetu Medycznego w Lublinie. Problemy Pielęgniarstwa 2008; 16: 72-80.

21. Walas L, Ślusarska B, Szyszkowska M, Zarzycka D. Rola kształcenia praktycznego w przygotowaniu do zawodu pielęgniarki. Medycyna Dydaktyka Wychowanie 2006; 38: $40-4$.

22. Szyszkowska M, Zarzycka D, Walas L, Ślusarska B. Podstawy wiedzy teoretycznej a praktyczna nauka zawodu studentów licencjackich studiów pielęgniarskich. Pielęgniarstwo XXI Wieku 2005; 4: 77-82.

23. Rezmerska L, Haor B, Andruszkiewicz A, Wrońska I. Proces kształcenia licencjackiego pielęgniarek w opinii studentów i nauczycieli akademickich Wydziału Pielęgniarstwa i Nauk o Zdrowiu Akademii Medycznej w Bydgoszczy. In: Kształcenie pielęgniarek na przestrzeni wieku. Międzynarodowa Konferencja Naukowa: Pielęgniarstwo wobec zagrożenia wartości. 100-lecie urodzin Hanny Chrzanowskiej, Kraków 2002.

24. Sulewska M, Mikulska A, Krupniewicz A. Opinie studentów I roku kierunku Pielęgniarstwo Wydziału Pielęgniarstwa i Nauk o Zdrowiu AM w Warszawie o pierwszych zajęciach praktycznych w klinikach. Medycyna Dydaktyka Wychowanie 2004; 36: 29-32.

\section{Address for correspondence:}

Prof. Joanna Gotlib MD, PhD

Division of Teaching and Outcomes of Education

Faculty of Health Science

Medical University of Warsaw

ul. Żwirki i Wigury 61, 02-091 Warsaw, Poland

Phone:+48 225720490

Fax: +48225720491

E-mail: joanna.gotlib@wum.edu.pl 